\title{
Comparative study of intravenous iron sucrose versus intravenous ferric carboxymaltose in the management of iron deficiency anaemia in pregnancy
}

\author{
Ferdousi Khatun, Chandralekha Biswas*
}

Department of Health and Family Welfare, Government of West Bengal, West Bengal, India

Received: 10 December 2021

Revised: 06 January 2022

Accepted: 07 January 2022

\author{
*Correspondence: \\ Dr. Chandralekha Biswas, \\ E-mail: chandralekhabiswas@gmail.com
}

Copyright: (c) the author(s), publisher and licensee Medip Academy. This is an open-access article distributed under the terms of the Creative Commons Attribution Non-Commercial License, which permits unrestricted non-commercial use, distribution, and reproduction in any medium, provided the original work is properly cited.

\begin{abstract}
Background: Iron deficiency anaemia is the most common anaemia with significant effect over health status. It is a major hematological, nutritional deficiency but manageable health problem among the pregnant women. Anaemia during pregnancy is associated with increased morbidity and mortality of pregnant women and their developing foetuses. In pregnant women, oral iron is often used for prophylaxis and is recommended as first-line treatment for iron deficiency anaemia in pregnancy. Intravenous (i.v.) iron preparations provide greater and more rapid repletion of iron stores than oral iron.

Methods: This is a prospective, single center, comparative interventional randomized hospital based study carried among antenatal mother admitted in antenatal ward in the department Obstetrics and Gynaecology, Medical college and hospital, Kolkata from $1^{\text {st }}$ January 2019 to $30^{\text {th }}$ June 2020 (one and half year duration), comprised of 180 pregnant women divided two groups. Group- A (90) received ferric carboxymaltose (FCM), group- B (90) received iron sucrose. All pregnant women between 16 to 34 weeks of gestation with iron deficiency anaemia with hemoglobin values between 7-10 gm\%, were counselled and included. Medical eligibility criteria were used for client selection.

Results: In FCM group 3 week post treatment hemoglobin level was $9.87 \pm 0.77$ and in iron sucrose group it was $9.39 \pm 0.72(\mathrm{p}=0.001) .6$ week post treatment hemoglobin level in FCM group was $11.51 \pm 0.76$ and in iron sucrose group it was $10.78 \pm 0.61(\mathrm{p}=0.001)$. Mean change in hemoglobin in FCM group after 3 week post treatment was $1.51 \pm 0.63$ and after 6 week it was 3.15 \pm 0.79 . In iron sucrose group at 3 week it was $1.16 \pm 0.43$ and at 6 week it was $2.55 \pm 0.52$. The mean change in hemoglobin level was higher among patients of FCM compared to Iron sucrose group.

Conclusions: Ferric carboxymaltose was safer and more efficient in treatment of iron deficiency anaemia in pregnant women as compared to iron sucrose with lesser adverse effect and better patient compliance.
\end{abstract}

Keywords: Ferric carboxymaltose, Iron deficiency anaemia, Iron sucrose

\section{INTRODUCTION}

Anemia the Greek word (anhaima) meaning "without blood" is the deficiency of red blood cell and or hemoglobin which result in a reduced oxygen carrying capacity of blood causing tissue hypoxia. Iron deficiency anemia is the most common anemia with significant effect over health status (FOGSI, 2016) and major hematological, nutritional deficiency but manageable health problem encountered among the pregnant women globally but more common in developing countries especially in tropics like India especially in under privileged population. ${ }^{1}$ According to WHO prevalence of anemia in developed and developing countries in pregnant women is $14 \%$ and $51 \%$ respectively. Prevalence of anemia in South Asian countries is the highest in the world. 
About half of the global maternal mortality due to anemia occur in South Asian countries and India contributes to $80 \%$ of it (Ezatti et al, 2002). ${ }^{2}$ WHO defined anemia in pregnancy as hemoglobin levels $<11 \mathrm{gm} \%$ and hematocrit $<33 \%$. Using $11 \mathrm{gm} / \mathrm{dl}$ as a cut off for the definition of anemia is probably too high for India and hence FOGSI (The Federation of Obstetric and Gynecological Societies of India) has suggested a cut off of hemoglobin of $10 \mathrm{gm} / \mathrm{dl}$ for India. ICMR (Indian medical Council and research) has categorized anemia during pregnancy as- mild anemiaHb- 10-10.9gm\%, moderate anemia- Hb- 7-9.9 gm\%, severe anemia- $\mathrm{Hb}-4-6.9 \mathrm{gm} \%$, very severe anemia- $\mathrm{Hb}-$ $<4$ gm\%. Iron deficiency in pregnancy has been defined by the National Academy of Science Panel on Nutrition and Pregnancy as ferritin level lower than $12 \mathrm{ng} / \mathrm{ml}$.

Anemia affects all age groups starting from puberty and adolescence to perimenopausal age. High incidence of anemia in India are because of low dietary intake of iron, poor bio-availability of iron, faulty food habits, phytate rich Indian diet, chronic blood loss during menses and high prevalence of infections like malaria and hookworm infestations. $^{3}$

In a typical singleton gestation, the maternal need for iron averages nearly $1000 \mathrm{mg}$. Multifetal gestation requirements are considerably higher. ${ }^{4}$ These amounts exceed the iron stores of most women and result in irondeficiency anemia unless supplementation is given.

During pregnancy, the physiological need for absorbed iron increases from $0.8 \mathrm{mg} /$ day in the first trimester to $7.5 \mathrm{mg} /$ day in the third trimester. Dietary iron intake does not compensate for this strongly increased iron demand. The modest fall in hemoglobin levels and hematocrit values during pregnancy is caused by a relatively greater expansion of plasma volume compared with the increase in red cell volume. The disproportion between the rates at which plasma and erythrocytes are added to the maternal circulation is greatest during the second trimester. The condition gets aggravated in pregnancy due to increase demand of the growing fetus. ${ }^{5}$

General symptoms of anemia are fatigue, dizziness, and impaired immune response predisposing to infections. Anemia during pregnancy is associated with increased morbidity and mortality of pregnant women and their developing fetuses. Iron deficiency anemia has been shown to be associated with an increased risk of premature birth, low birth weight baby, preeclampsia, placental abruption, and increased peripartum blood loss as well as cardiac failure and related death. 6,7

In pregnant women, oral iron is often used for prophylaxis of iron deficiency and is recommended as first-line treatment for pregnant women with iron deficiency anemia. ${ }^{8}$ However, oral iron substitution has shown to be insufficient for the treatment of moderate to severe iron deficiency anemia in second and third trimester, and is often associated with noncompliance due to gastrointestinal side effects like nausea, diarrhea, heartburn, bloating, constipation and dark stools. Therefore, guidelines recommend that physicians consider intravenous (i.v.) iron administration in pregnant women in case of iron deficiency anemia ( $\mathrm{Hb}<9.0 \mathrm{gm} / \mathrm{dl})$, intolerability to oral iron, insufficient hemoglobin increase after oral iron treatment or if there is a need for rapid hemoglobin reconstitution. ${ }^{9,10}$ Intravenous (i.v.) iron preparations provide greater and more rapid repletion of iron stores than oral iron therapy without the gastrointestinal side effects associated with oral substitution. Parenteral therapy promises a better response in anemic patients and can obviate the need for blood transfusions in the antenatal and postpartum period. ${ }^{11}$

The most commonly used intravenous iron preparation is iron sucrose. It does not require test dose and safe. The only disadvantage is limited dose can be given at one time. The maximum permissible dose is $200 \mathrm{mg}$ per day or 600 $\mathrm{mg}$ per week and requires multiple hospital visits and puts a heavy burden on hospital resources.

Ferric carboxymaltose (FCM) is the latest i.v. iron formulation which can be used at high doses and allows rapid administration (up to $1000 \mathrm{mg}$ in a single dose infused in 15 minutes). Because it is free of dextran and its derivatives, FCM does not cross-react with dextran antibodies and never needed the administration of a test dose. FCM molecule is novel iron complex which consist ferric hydroxide core chelated in a carbohydrate shell and this complex taken up by macrophages as a whole avoiding iron toxicity and oxidative stress. ${ }^{12}$

The present study was a comparative study of parenteral iron therapy (intravenous iron sucrose versus intravenous ferric carboxymaltose in the management of iron deficiency anaemia in pregnancy.

\section{METHODS}

This was a prospective, single center, comparative interventional randomized hospital-based study carried among antenatal mother admitted in antenatal ward in the department Obstetrics and Gynecology, Medical college and hospital, Kolkata from $1^{\text {st }}$ January 2019 to $30^{\text {th }}$ June 2020 (one and half year duration). Pregnant women aged 18 year and above with iron deficiency anemia admitted in the antenatal word of the above hospital. After taking informed consent, the pregnant women who met the eligibility criteria were included in the study.

The eligibility criteria were pregnant women with iron deficiency anemia with hemoglobin values between 7-10 gm\%, gestational age 16-34 weeks and single viable fetus with no anomalies. Pregnant women with anemia due to causes other than iron deficiency, history of blood transfusion and erythropoietin treatment in present pregnancy, other medical disorders complicating pregnancy or history of hematological diseases, specific allergy to iron derivatives were excluded from this study. 
Total 180 pregnant women were selected and divided into two groups i.e. group- A (90 pregnant mother) and groupB (90 pregnant women) received FMC and iron sucrose respectively.

A well designed pro forma containing various parameters under study was used for data collection. The data was maintained in computer Written and informed consent was taken after counselling. All the consequences and benefits of the therapy was explained to patient. After inclusion in study, detailed history of each patient was taken including age, medical history, obstetric history menstrual history and family history. To determine socio-economic status of those patients we used Modified Kuppuswamy's Scale. Detailed physical examination was carried out along with investigations like hemoglobin, serum Ferritin and peripheral smear. They were randomly divided in two equal groups using a computer generated table. Group A received $1 \mathrm{gm}$ of i.v. ferric carboxymaltose (as single dose) diluted in $200 \mathrm{ml} 0.9 \%$ normal saline over 30 minutes. Group B was treated with total dose of $1 \mathrm{gm}$ of iron sucrose which were divided in four equal doses on day 1 , day 3 , day 5 , day 7 (i.e. $250 \mathrm{mg}$ each) diluted in $100 \mathrm{ml}$ of $0.9 \%$ normal saline given slow i.v. over 30 minutes on indoor basis. During and 1 hour after infusion each patient was monitored in the ward for any adverse reactions. After completion of the regimen patients were discharged from ward and each patient was followed up for rise of hemoglobin, serum ferritin and peripheral smear change at $3^{\text {rd }}$ week and $6^{\text {th }}$ weeks after completion of therapy. The results were noted in preformed pro forma for each patient. Any adverse drug reactions during infusion and in follow up period were recorded.

\section{Statistical analysis}

The results were presented in frequencies, percentages and mean \pm SD. The Chi-square test was used to compare categorical variables between the groups. The unpaired ttest was used to compare continuous variables between the groups. The paired t-test was used to compare mean change in continuous variables. The $p$ value $<0.05$ was considered significant. All the analysis was carried out on SPSS 16.0 version (Chicago. Inc., USA).

\section{RESULTS}

Results of our study are tabulated as follows:

Table 1: Distribution of gestational age between the groups.

\begin{tabular}{|lllll|}
\hline Gestational & \multicolumn{2}{l}{ FCM $(\mathbf{n}=\mathbf{9 0})$} & \multicolumn{2}{l|}{ Iron sucrose $(\mathbf{n = 9 0})$} \\
\cline { 2 - 5 } age in weeks & No. & $\mathbf{\%}$ & No. & $\mathbf{\%}$ \\
\hline$<\mathbf{2 0}$ & 14 & 15.6 & 25 & 27.8 \\
\hline $\mathbf{2 0 - 2 5}$ & 32 & 35.6 & 24 & 26.7 \\
\hline $\mathbf{2 6 - 3 0}$ & 36 & 40.0 & 36 & 40.0 \\
\hline$>\mathbf{3 0}$ & 8 & 8.9 & 5 & 5.6 \\
\hline Mean \pm SD & $24.86 \pm 4.48$ & $23.92 \pm 4.65$ \\
\hline
\end{tabular}

Table 1, shows the distribution of gestational age between the groups. More than one third of patients of both FCM $(40 \%)$ and iron sucrose $(40 \%)$ had gestational age $26-30$ weeks. The mean gestational age of patients of FCM and Iron sucrose was $24.86 \pm 4.48$ and $23.92 \pm 4.65$ weeks respectively.

Table 2: Comparison of parity between the groups.

\begin{tabular}{|lllll|}
\hline \multirow{2}{*}{ Parity } & \multicolumn{2}{l}{ FCM $(\mathbf{n = 9 0 )}$} & \multicolumn{2}{l|}{ Iron sucrose $(\mathbf{n = 9 0})$} \\
\hline Nil & No. & \% & No. & \% \\
\hline One & 20 & 22.2 & 29 & 32.2 \\
\hline Two & 45 & 50.0 & 19 & 21.1 \\
\hline$\geq$ Three & 9 & 16.8 & 32 & 35.6 \\
\hline
\end{tabular}

Table 2, shows the comparison of parity between the groups. $22.2 \%$ patients in the FCM group and $32.2 \%$ in Iron sucrose group were nulliparous. $77.8 \%$ in FCM group and $67.8 \%$ patient in iron sucrose group had previous history of childbirth. In either group anemia was more common in multiparous women.

Table 3: Comparison of inter pregnancy intervals between the groups.

\begin{tabular}{|lll|ll|}
\hline $\begin{array}{l}\text { Inter pregnancy } \\
\text { interval in years }\end{array}$ & \multicolumn{2}{c|}{ FCM $(\mathbf{n = 7 6 )}$} & \multicolumn{2}{l|}{$\begin{array}{l}\text { Iron sucrose } \\
(\mathbf{n = 8 1 )}\end{array}$} \\
\cline { 2 - 5 } & No. & $\mathbf{\%}$ & No. & \% \\
\hline One & 31 & 40.8 & 38 & 46.9 \\
\hline Two & 35 & 46.1 & 32 & 39.5 \\
\hline$\geq$ Three & 10 & 13.2 & 11 & 13.6 \\
\hline
\end{tabular}

Table 3, shows the comparison of inter pregnancy interval between the groups. More than one third of patients of iron sucrose $(46.9 \%)$ and of FCM $(40.8 \%)$ group had 1 years of inter pregnancy interval. However, and $39.5 \%$ of iron sucrose and $46.1 \%$ of FCM had 2 year inter pregnancy interval.

Table 4: Comparison of SES between the groups.

\begin{tabular}{|lllll|}
\hline \multirow{2}{*}{ SES } & \multicolumn{2}{l}{ FCM $(\mathbf{n = 9 0 )}$} & \multicolumn{2}{c|}{ Iron sucrose $(\mathbf{n = 9 0})$} \\
\hline I & No. & $\mathbf{\%}$ & No. & $\mathbf{\%}$ \\
\hline II & 7 & 7.8 & 1 & 1.1 \\
\hline III & 22 & 35.6 & 22 & 24.4 \\
\hline IV & 27 & 24.4 & 32 & 35.6 \\
\hline V & 2 & 30.0 & 29 & 32.2 \\
\hline
\end{tabular}

Table 4, shows the comparison of SES between the groups. $7.8 \%$ patient in FCM group and $1.1 \%$ patient in Iron sucrose group were in upper class. More than half of the patient in FCM group 56.6\% and approximately three fourth of the patient in IRON SUCROSE group $74.5 \%$ belonged to low socio-economic status which clearly indicate that anemia is prevalent in low socio-economic status. Modified Kuppuswamy's scale: Class I- upper, 
class II- upper middle, class III- lower middle, class IVupper lower, class IV- lower.

Table 5: Comparison of $\mathrm{Hb}$ between the groups across the time periods.

\begin{tabular}{|llll|}
\hline Time periods & $\begin{array}{l}\text { FCM } \\
(\mathbf{n}=90)\end{array}$ & $\begin{array}{l}\text { Iron sucrose } \\
(\mathbf{n}=90)\end{array}$ & P value $^{1}$ \\
\hline Pre-treatment & $8.36 \pm 0.84$ & $8.23 \pm 0.73$ & 0.27 \\
\hline $\begin{array}{l}\text { Post-treatment } \\
\text { 3 weeks }\end{array}$ & $9.87 \pm 0.77$ & $9.39 \pm 0.72$ & $0.001^{*}$ \\
\hline $\begin{array}{l}\text { Post-treatment } \\
\text { 6 weeks }\end{array}$ & $11.51 \pm 0.76$ & $10.78 \pm 0.61$ & $0.001^{*}$ \\
\hline
\end{tabular}

${ }^{1}$ Unpaired t-test, *Significant

Table 5 shows the comparison of $\mathrm{Hb}$ level between the groups across the time periods. There was significant $(p=0.001)$ difference in $\mathrm{Hb}$ level between the groups at post treatment 3 and 6 weeks.

Table 6: Comparison of mean change in $\mathrm{Hb}$ within the groups from pre-treatment to time periods.

\begin{tabular}{|l|llll|}
\hline $\begin{array}{l}\text { Time } \\
\text { periods }\end{array}$ & $\begin{array}{l}\text { Mean } \\
\text { change }\end{array}$ & $\begin{array}{l}\text { P } \\
\text { value }^{1}\end{array}$ & $\begin{array}{l}\text { Mean } \\
\text { change }\end{array}$ & $\begin{array}{l}\text { P } \\
\text { value }^{1}\end{array}$ \\
\hline $\begin{array}{l}\text { Pre- } \\
\text { treatment } \\
\text { to post- } \\
\text { treatment } \\
\text { 3 weeks }\end{array}$ & $1.51 \pm 0.63$ & $0.001^{*}$ & $1.16 \pm 0.43$ & $0.001^{*}$ \\
\hline $\begin{array}{l}\text { Pre- } \\
\text { treatment } \\
\text { to post- } \\
\text { treatment } \\
\text { 6 weeks }\end{array}$ & $3.15 \pm 0.79$ & $0.001^{*}$ & $2.55 \pm 0.52$ & $0.001^{*}$ \\
\hline
\end{tabular}

${ }^{1}$ Paired t-test, *Significant

Table 6 shows the comparison of mean change in Hb level within the groups from pre-treatment to time periods. There was significant $(\mathrm{p}=0.001)$ mean change in Hb level in both the groups from pre-treatment to 3 and 6 weeks. The mean change in $\mathrm{Hb}$ level was higher among patients of FCM compared to Iron sucrose.

Table 7: Comparison of ferritin level between the groups across the time periods.

\begin{tabular}{|llll|}
\hline Time periods & $\begin{array}{l}\text { FCM } \\
(\mathbf{n}=90)\end{array}$ & $\begin{array}{l}\text { Iron sucrose } \\
(\mathbf{n}=90)\end{array}$ & P value $^{1}$ \\
\hline $\begin{array}{l}\text { Pre- } \\
\text { treatment }\end{array}$ & $11.40 \pm 1.19$ & $11.44 \pm 1.28$ & 0.82 \\
\hline $\begin{array}{l}\text { Post- } \\
\text { treatment 3 } \\
\text { weeks }\end{array}$ & $78.14 \pm 9.45$ & $44.55 \pm 11.02$ & $0.001^{*}$ \\
\hline $\begin{array}{l}\text { Post- } \\
\text { treatment 6 } \\
\text { weeks }\end{array}$ & $100.11 \pm 6.66$ & $67.82 \pm 12.83$ & $0.001^{*}$ \\
\hline${ }^{1}$ Unpaired t-test, *Significant & & \\
\hline
\end{tabular}

Table 7 shows the comparison of mean change in $\mathrm{Hb}$ level within the groups from pre-treatment to time periods. There was significant $(p=0.001)$ mean change in $\mathrm{Hb}$ level in both the groups from pre-treatment to 3 and 6 weeks. The mean change in $\mathrm{Hb}$ level was higher among patients of FCM compared to Iron sucrose.

Table 8: Comparison of mean change in ferritin level within the groups from pre-treatment to time periods.

\begin{tabular}{|l|l|ll|l|}
\hline $\begin{array}{l}\text { Time } \\
\text { periods }\end{array}$ & $\begin{array}{l}\text { FCM }(\mathrm{n}=90) \\
\text { Mean } \\
\text { change }\end{array}$ & P value $^{1}$ & $\begin{array}{l}\text { Iron sucrose }(\mathbf{n = 9 0}) \\
\text { Mean } \\
\text { change }\end{array}$ & P value \\
\hline $\begin{array}{l}\text { Pre- } \\
\text { treatment } \\
\text { to post- } \\
\text { treatment } \\
\text { 3 weeks }\end{array}$ & $66.74 \pm 9.38$ & $0.0001 *$ & $33.11 \pm 11.11$ & $0.0001 *$ \\
\hline $\begin{array}{l}\text { Pre- } \\
\text { treatment } \\
\text { to post- } \\
\text { treatment } \\
6 \text { weeks }\end{array}$ & $88.71 \pm 6.63$ & $0.0001 *$ & $56.38 \pm 12.55$ & $0.0001 *$ \\
\hline
\end{tabular}

${ }^{1}$ Paired t-test, *Significant

Table 8 shows the comparison of mean change in ferritin level within the groups from pre-treatment to time periods. There was significant $(\mathrm{p}=0.001)$ mean change in ferritin level in both the groups from pre-treatment to 3 and 6 weeks. The mean change in ferritin level was higher among patients of FCM compared to Iron sucrose.

Table 9: Comparison of PBS between the groups from pre-treatment to subsequent time periods.

\begin{tabular}{|c|c|c|c|c|c|}
\hline \multirow[t]{2}{*}{ Time periods } & \multicolumn{2}{|c|}{$\begin{array}{l}\text { FCM } \\
(n=90)\end{array}$} & \multicolumn{2}{|c|}{$\begin{array}{l}\text { Iron sucrose } \\
(n=90)\end{array}$} & \multirow{2}{*}{$\begin{array}{l}\mathbf{P} \\
\text { value }^{1}\end{array}$} \\
\hline & No. & $\%$ & No. & $\%$ & \\
\hline \multicolumn{6}{|l|}{ Pretreatment } \\
\hline $\begin{array}{l}\text { Microcytic } \\
\text { hypochromic }\end{array}$ & 84 & 93.3 & 79 & 87.8 & \multirow{2}{*}{0.20} \\
\hline $\begin{array}{l}\text { Normocytic } \\
\text { normochromic }\end{array}$ & 6 & 6.7 & 11 & 12.2 & \\
\hline \multicolumn{6}{|c|}{ Post-treatment 3 weeks } \\
\hline $\begin{array}{l}\text { Microcytic } \\
\text { hypochromic }\end{array}$ & 63 & 70.0 & 73 & 81.1 & \multirow{3}{*}{0.11} \\
\hline $\begin{array}{l}\text { Normocytic } \\
\text { hypochromic }\end{array}$ & 2 & 2.2 & 0 & 0.0 & \\
\hline $\begin{array}{l}\text { Normocytic } \\
\text { normochromic }\end{array}$ & 25 & 27.8 & 17 & 18.9 & \\
\hline \multicolumn{6}{|c|}{ Post-treatment 6 weeks } \\
\hline $\begin{array}{l}\text { Microcytic } \\
\text { hypochromic }\end{array}$ & 46 & 51.1 & 61 & 67.8 & \multirow{3}{*}{0.06} \\
\hline $\begin{array}{l}\text { Normocytic } \\
\text { hypochromic }\end{array}$ & 1 & 1.1 & 0 & 0.0 & \\
\hline $\begin{array}{l}\text { Normocytic } \\
\text { normochromic }\end{array}$ & 43 & 47.8 & 29 & 32.2 & \\
\hline
\end{tabular}


Table 9 shows the comparison of PBS between the groups from pre-treatment to subsequent time periods. There was no significant $(\mathrm{p}>0.05)$ difference in PBS at all the time periods between the groups.

Table 10: Comparison of adverse reactions between the groups.

\begin{tabular}{|c|c|c|c|c|c|}
\hline \multirow[t]{2}{*}{ Time periods } & \multicolumn{2}{|c|}{$\begin{array}{l}\text { FCM } \\
(n=90)\end{array}$} & \multicolumn{2}{|c|}{$\begin{array}{l}\text { Iron sucrose } \\
(\mathbf{n}=90)\end{array}$} & \multirow[t]{2}{*}{ P value $^{1}$} \\
\hline & No. & $\%$ & No. & $\%$ & \\
\hline $\begin{array}{l}\text { Injection site } \\
\text { swelling }\end{array}$ & 4 & 4.4 & 7 & 7.8 & \multirow{7}{*}{ NA } \\
\hline Muscle cramp & 0 & 0.0 & 3 & 3.3 & \\
\hline Nausea & 2 & 2.2 & 5 & 5.6 & \\
\hline $\begin{array}{l}\text { Nausea, } \\
\text { vomiting }\end{array}$ & 5 & 5.6 & 6 & 6.7 & \\
\hline Pruritus & 2 & 2.2 & 0 & 0.0 & \\
\hline $\begin{array}{l}\text { Redness on } \\
\text { injection site }\end{array}$ & 5 & 5.6 & 0 & 0.0 & \\
\hline None & 72 & 80.0 & 69 & 76.7 & \\
\hline
\end{tabular}

${ }^{1}$ Chi-square test, *Significant

Table 10 shows the comparison of adverse reactions between the groups. The adverse reactions was lower among patients of FCM than iron sucrose.

\section{DISCUSSION}

The aim of our study was to compare the safety and efficacy of injection ferric carboxymaltos with injection iron sucrose in antenatal women with iron deficiency anaemia.

Table 1 shows the distribution of gestational age between the two groups. In our study more than one third of patients of both FCM (40\%) and iron sucrose (40\%) had gestational age 26-30 weeks. The mean gestational age of patients of FCM and iron sucrose was $24.86 \pm 4.48$ and $23.92 \pm 4.65$ weeks respectively. In the study by Bhavi et al, most of the patients were between 31 and 34 weeks of gestation at diagnosis. ${ }^{13}$ This showed that iron deficiency occurs in late $2^{\text {nd }}$ trimester and $3^{\text {rd }}$ trimester which may be due to hemodilution and increased iron requirement.

Table 2 shows the comparison of parity between the groups. $22.2 \%$ patients in the FCM group and $32.2 \%$ in iron sucrose group were nulliparous. $77.8 \%$ in FCM group and $67.8 \%$ patient in iron sucrose group had previous history of childbirth. In either group anemia was more common in multiparous women. In either group anemia was more common in multiparous women. Study done by Mekonnen et al showed $54 \%$ of the study population had one or more previous pregnancies. ${ }^{14}$ In the study of UcheNwachi et al, it was found that women with at least one previous birth or pregnancy were more likely to have anaemia than women without any. ${ }^{15}$ This finding was similar to our study. Increased prevalence of anemia was due to decreased iron store as a result of repeated child birth, blood loss during delivery and associated medical factors.

Table 3 shows the comparison of inter pregnancy interval between the groups. More than one third of patients of iron sucrose $(46.9 \%)$ and of FCM (40.8\%) group had 1 years of inter pregnancy interval. However, and $39.5 \%$ of iron sucrose and $46.1 \%$ of FCM had 2 year inter pregnancy interval in our study. Study done by Lazovic et al showed the results of haemoglobin indicating anaemia were found in a greater number as pregnancy progressed in women with shorter time-interval between deliveries. ${ }^{16}$ The lack of adequate birth spacing likely contributed to anemia in these study populations.

Table 4 shows the comparison of SES between the groups. $7.8 \%$ patient in FCM group and $1.1 \%$ patient in iron sucrose group were in upper class. More than half of the patient in FCM group 56.6\% and approximately three fourth of the patient in iron sucrose group $74.5 \%$ belonged to low socio-economic status which clearly indicate that anemia is prevalent in low socio-economic status. Lunagariya et al found that total $88 \%$ patients were from lower socio-economic class. ${ }^{17}$ It was consistent with the population characteristics in studies conducted by Noronha et al, Singh et al and Garg et al in which majority of anaemic women were from lower socio economic class. ${ }^{18-20}$

In this study, there was significant $(\mathrm{p}=0.001)$ difference in $\mathrm{Hb}$ level between the groups at post treatment 3 and 6 weeks. There was significant $(p=0.001)$ mean change in $\mathrm{Hb}$ level in both the groups from pre-treatment to posttreatment 3 and 6 weeks. In FCM group the mean rise of $\mathrm{Hb}$ from pretreatment to post treatment 3 week was $1.51 \pm 0.63$ and post treatment 6 week was $3.15 \pm 0.79$. In iron sucrose it was $1.16 \pm 0.43$ at post treatment 3 week and $2.55 \pm 0.52$ at post treatment 6 week. The mean change in $\mathrm{Hb}$ level was higher among patients of FCM group compared to Iron sucrose group (Tables 5 and 6). Kumari et al found that hemoglobin was increased in both the groups (iron sucrose and FCM). ${ }^{21}$ Patients when received iron sucrose hemoglobin was increased from $8.27 \mathrm{gm} \%$ to 10.48 gm\% post therapy while, who were given ferric carboxymaltose hemoglobin increased from $8.3 \mathrm{gm} \%$ to $11.83 \mathrm{gm} \%$. Bayoumeu et al showed the rise of hemoglobin from $9.6 \pm 0.7 \mathrm{gm}$ to $11.11 \pm 1.3 \mathrm{gm} / \mathrm{dl} 4$ weeks after the treatment with iron sucrose. ${ }^{22}$

VanWyck et al reported increase of hemoglobin by $2 \mathrm{gm} / \mathrm{dl}$ in $1^{\text {st }}$ week and $4 \mathrm{gm} / \mathrm{dl}$ by $2-4$ weeks of therapy in those receiving FCM. ${ }^{23}$ Jose et al, showed that the mean rise in $\mathrm{Hb}$ at 12 weeks was significantly higher in FCM group than iron sucrose group ( $29 \mathrm{gm} / \mathrm{l}$ versus $22 \mathrm{gm} / \mathrm{l}) .{ }^{24}$ Study done by Khan et al, showed statistically significant rise in $\mathrm{Hb}$ in FCM group as compared to that of iron sucrose (1.79 versus $1.06 \mathrm{gm} / \mathrm{dl}) .{ }^{25}$ In study of Sumathy et al, increase in level of hemoglobin among iron sucrose group was observed by $1.65 \mathrm{gm} / \mathrm{dl}$ and $2.35 \mathrm{gm} / \mathrm{dl}$ after 2 and 4 weeks of treatment. ${ }^{26}$ Similarly in case of FCM groups they 
observed the increase by 2.04 and $2.83 \mathrm{gm} / \mathrm{dl}$ at 2 and 4 weeks of treatment. According to Giannoulis et al, the mean rise of hemoglobin by $4-6 \mathrm{gm} / \mathrm{dl}$ in patients who received iron sucrose. ${ }^{27}$ Patel et al estimated $\mathrm{Hb}$ level in pregnant women pre and post iron therapy. ${ }^{28}$ They observed that in females receiving iron sucrose hemoglobin levels increased by $4.1 \mathrm{gm} / \mathrm{dl}$ while in those receiving FCM the mean rise was $5.2 \mathrm{gm} / \mathrm{dl}$. Similar pattern of increment was also observed in our study.

This study showed that there was significant $(p=0.001)$ difference in ferritin level between the groups at post treatment 3 and 6 weeks. There was significant $(\mathrm{p}=0.001)$ mean change in ferritin level in both the groups from pretreatment to post-treatment 3 and 6 weeks. In FCM group the mean rise of ferritin from pretreatment to post treatment 3 week was $66.74 \pm 9.38$ and post treatment 6 week was $88.71 \pm 6.63$. In iron sucrose group it was $33.11 \pm 11.11$ at post treatment 3 week and $56.38 \pm 12.55$ at post treatment 6 week. The mean change in ferritin level was higher among patients of FCM compared to iron sucrose (Tables 7 and 8). Kumari et al showed that levels of serum ferritin was increased from $77.91 \mathrm{ng} / \mathrm{dl}$ to 182.86 $\mathrm{ng} / \mathrm{dl}$ in iron sucrose group and from $78.05 \mathrm{ng} / \mathrm{dl}$ to 195.39 $\mathrm{ng} / \mathrm{dl}$ in FCM group patients. ${ }^{21}$ In a study by Lunagariya et al also reported significant increase in serum ferritin in FCM group compared to Iron sucrose group. ${ }^{17}$ In their study, level of ferritin increased from $13.34 \pm 3.37$ to $83.95 \pm 14.37$ in FCM group while in Iron sucrose group, the value increased from $14.166 \pm 3.55$ to $76.06 \pm 16.56$ $\mathrm{mg} / \mathrm{dl}$. Study done by Khan et al showed that increase in serum ferritin was significantly higher in the FCM group compared to iron sucrose group (123.80 versus 84.78 $\mu \mathrm{g} / \mathrm{l}){ }^{25}$ Kharde et al elucidated the mean increase of ferritin level from $11.47 \mathrm{ng} / \mathrm{ml}$ to $47.69 \mathrm{ng} / \mathrm{ml}$ and 53.47 $\mathrm{ng} / \mathrm{ml}$ at $2^{\text {nd }}$ and $6^{\text {th }}$ week of treatment with iron sucrose. ${ }^{29}$ A study done by Agrawal et al showed that iron sucrose raised serum ferritin by $31.64 \mu \mathrm{g} / \mathrm{dl}$ in comparison to ferric carboxymaltose where serum ferritin was raised by 64.97 $\mu \mathrm{g} / \mathrm{dl}$ at 3 weeks post iron therapy. ${ }^{30}$

In our study, there was no significant ( $p>0.05)$ difference in PBS at all the time periods between the groups (Table 9).

Our study found that the adverse reactions was lower among patients of FCM than Iron sucrose (Table 10). Malek et al and Khalafallah et al reported FCM to be more effective with less side effects and better compliance compared Iron sucrose group. ${ }^{31,32}$ Seid et al in their controlled randomized clinical trial assessed the efficacy and safety of FCM and oral ferrous sulphate. ${ }^{33}$ They reported that treatment with FCM were more effective and safer.

Thus our study shows that ferric carboxymaltose is safe as parenteral iron therapy during pregnancy and it is better in correction of iron deficiency anemia as well as replenishment of iron store than iron sucrose. Compared to iron sucrose, ferric carboxymaltose has advantage of large dose administration per sitting, early rise of haemoglobin, lesser total number of doses required and less side effects, which make treatment safe, short, and cost effective. Patient's compliance is more in ferric carboxymaltose treatment as it requires less frequent visits which reduce transport cost and it reduces discomfort due to multiple needle puncture. Similarly, as per Garg et al, FCM is more effective, safe and easy to administer as it is required in single dose compared to small and multiple doses of iron sucrose. ${ }^{20}$

One of the limitation of our study was small sample size and short duration of study period.

\section{CONCLUSION}

The findings of our study showed significant increase in $\mathrm{Hb}$ and ferritin level in both the group after treatment but the rise was more among those who received injection FCM than injection iron sucrose. This study also established that FCM is safer than Iron sucrose. Treatment with FCM resulted in rapid replenishment of iron stores in pregnant women with significantly high rise of $\mathrm{Hb}$ and ferritin over a 6 weeks period with lesser adverse effects. The convenient dosing with lesser total number of required doses resulted good compliance. Because of high efficacy and safety of FCM it must be used as a first line drug in the management of Iron deficiency anemia in pregnancy to decrease high incidence and burden of the disease on our society set up.

Overall, this study concluded that Ferric carboxymaltose was safer and more efficient in treatment of iron deficiency anemia in pregnant women as compared to iron sucrose with lesser adverse effect and better patient compliance.

Funding: No funding sources

Conflict of interest: None declared

Ethical approval: The study was approved by the Institutional Ethics Committee

\section{REFERENCES}

1. FOGSI General Clinical Practice Recommendations. Management of iron deficiency anaemia in pregnancy. 2016. Available from: https://www.fogsi.org/wpcontent/uploads/2016/05/The-evidence-base_IDAPregnancy-24-May-2016-Clean.pdf. Accessed on 3 May 2020.

2. Ezatti M, Lopez AD, Rodgers A, Vander Hoorn S, Murray CJL. Comparative risk assessment collaborating group. Selected major risk factors and global and regional burden of disease. Lancet Lond Engl. 2002;360(9343):1347-60.

3. Singh P, Tuteja GS. Micronutrient profile of Indian children and women: summary of available data for iron and vitamin A. Indian Pediatr. 2003;40(5):477-9.

4. Galan P, Yoon HC, Preziosi P, Viteri F, Valeix P, Fieux B, et al. Determining factors in the iron status 
of adult women in the SU. VI. MAX study. Eur J Clin Nutr. 1998;52(6):383-8.

5. Milman N, Bergholt T, Byg KE, Eriksen L, Graudal $\mathrm{N}$. Iron status and iron balance during pregnancy. A critical reappraisal of iron supplementation, Acta Obstet Gynecol Scand. 1999;78(9):749-57.

6. Scholl TO. Iron status during pregnancy: setting the stage for mother and infant. Am $\mathrm{J}$ Clin Nutr. 2005;81(5):218s-1222s.

7. Arnold DL, Williams MA, Miller RS, Qiu C, Sorensen TK. Iron deficiency anemia, cigarette smoking and risk of abrupti placentae. J Obstet Gynaecol Res. 2009;35(3):446-52.

8. Breymann C, Honegger C, Holzgreve W, Surbek D. Diagnosis and treatment of iron-deficiency anemia during pregnancy and postpartum. Arch Gynecol Obstet. 2010;282(5):577-80.

9. Milman N. Prepartum anaemia: prevention and treatment. Ann Hematol. 2008;87(12):949-59.

10. Beris P, Maniatis A. Guidelines on intravenous iron supplementation in surgery and obstetrics/gynecology. Transfus Alternat Transfus Med. 2007;9:29-30.

11. Kriplani A, Mahey R, Dash BB, Kulshreshta V, Agarwal N, Bhatia N, Intravenous iron sucrose therapy for moderate anemia to severe anemia in pregnancy. Indian J Med Res. 2013;38:78.

12. Geisser P. The pharmacology and safety profile of ferric carboxymaltose (Ferinject): structure/reactivity relationships of iron preparations. Portuguese $\mathbf{J}$ Nephrol Hypertens. 2009;23(1):11-21.

13. Bhavi SB, Jaju PB. Intravenous iron sucrose versus oral ferrous fumarate for treatment of anemia in pregnancy. A randomized controlled trial. BMC Pregnancy Childbirth. 2017;17(1):1-6.

14. Mekonnen FA, Ambaw YA, Neri GT. Socioeconomic determinants of anemia in pregnancy in North Shoa Zone, Ethiopia. PLoS One. 2018;13(8).

15. Uche-Nwachi EO, Odekunle A, Jacinto S, Burnett M, Clapperton M, David Y, et al. Anaemia in pregnancy: associations with parity, abortions and child spacing in primary healthcare clinic attendees in Trinidad and Tobago. Afr Health Sci. 2010;10(1):66-70.

16. Lazović N, Pocekovac P. The importance of time intervals between childbirth and anemia in pregnancy. Srp Arh Celok Lek. 1996;124(11-12):307-10.

17. Lunagariya M, Nakum KD, Vithal A, Patel J, Patel M. Iron sucrose versus ferric carboxymaltose: in search of better treatment option in cases of post-partum iron deficiency anemia. Int $\mathbf{J}$ Contemp Med Res. 2018;5(1):12-6.

18. Noronha JA, Bhaduri A, Bhat HV. Prevalence of anaemia among pregnant women: a community based study in Udupi District. Health Popul Perspect Issues. 2008;31(1):31-40.

19. Singh H. Pregnancy-how effective is intravenous iron sucrose therapy? Int J Rec Scient. 2015;6(7):4900-7.

20. Garg R, Nigam A, Agrawal P, Nigam A, Agrawal R. Iron carboxymaltose: a safe and effective molecule to combat anaemia in pregnancy. Int $\mathbf{J}$ Curr Res Aca. 2016;4(2):124-30.

21. Kumari S, Singh SHK. Iron sucrose or ferric carboxy maltose: comparative study for treatment of postpartum iron deficiency anemia. Int $\mathrm{J}$ Med Res Prof. 2019;5(1):157-62.

22. Bayoumeu F, Subiran-Buisset C, Baka NE, Legagneur H, Monnier-Barbarino P, Laxenaire MC. Iron therapy in iron deficiency anemia in pregnancy: Intravenous route verses oral route. Am J Obstet Gynecol. 2002;186(3):518-22.

23. VanWyck DB, Martens MG, Seid MH, Baker JB, Mangione A. Intravenous ferric carboxymaltose compared with oral iron in the treatment of postpartum anaemia: a randomized controlled trial. Obstet Gynecol. 2007;110:267-78.

24. Jose A, Mahey R, Sharma JB, Bhatla N, Saxena R, Kalaivani $\mathrm{M}$, et al. Comparison of ferric Carboxymaltose and iron sucrose complex for treatment of iron deficiency anemia in pregnancyrandomised controlled trial. BMC Pregnancy Childbirth. 2019;19(1):1-8.

25. Khan S, Gupta S. A comparative study of injection ferric carboxymaltose and iron sucrose in anaemia complicating pregnancy. Int $\mathrm{J}$ Contemp Med Res. 2019;6(8).

26. Sumathy C, Arulmozhi V. Comparative study of intravenous ferric carboxymaltose and iron sucrose in the management of iron deficiency anemia. Paripex Indian J Res. 2017;6(4):91-4.

27. Giannoulis C, Danniilides A, Tantanasis T, Dinas K, Tzafettas J. Intravenous administration of iron sucrose for treating anaemia in postpartum women. Hippokratia. 2009;13(1):38-40.

28. Patel J, Patel K, Patel J, Sharma A, Date SK. Comparison of intravenous iron sucrose and ferric carboxymaltose therapy in iron deficiency anemia during pregnancy and postpartum period. J Pharm Sci Bioscient Res. 2015;5(3):239-43.

29. Kharde PS, Bangal BV, Panicker KK. Comparative study of intravenous iron sucrose versus oral iron therapy in iron deficiency anemia during postpartum period. IJBAR. 2012;3(4):238-43.

30. Neogi SB, Devasenapathy N, Singh R, Bhushan H, Shah D, Divakar H, et al. Safety and effectiveness of intravenous iron sucrose vs standard oral iron therapy in pregnant women with moderate to severe anemia in India. Lancet. 2019;7(12):1706-16.

31. Malek A. In vitro studies of ferric carboxymaltose on placenta permeability using the dual perfusion model of human placenta. Arzneimittelforschung. 2010;60(6a):354.61

32. Khalafallah A, Dennis A, Bates J, Bates G, Robertson IK, Smith L, et al. A prospective randomized controlled trial on intravenous versus oral iron for moderate iron deficiency anaemia of pregnancy. $\mathrm{J}$ Intern Med. 2010;268:286-95.

33. Seid MH, Derman RJ, Baker JB, Banach W, Goldberg C, Rogers R. Ferric carboxymaltose injection in the treatment of postpartum iron deficiency anaemia: a 
randomized controlled clinical trial. Am J Obstet Gynecol. 2008;199(4):435.e1-7.
Cite this article as: Khatun F, Biswas C.

Comparative study of intravenous iron sucrose versus intravenous ferric carboxymaltose in the management of iron deficiency anaemia in pregnancy. Int $\mathrm{J}$ Reprod Contracept Obstet Gynecol 2022;11:505-12. 